\title{
STUDY OF SHEAR BEHAVIOUR OF YAMUNA SAND BLENDED WITH SOFT SOIL
}

\author{
Deepak Rana ${ }^{1}$, Ankit Soni ${ }^{2}$, Farukh Ali $^{3}$ \\ ${ }^{I}$ M. Tech (Geotechnical Engineering), Department of Civil Engineering, Delhi Technological University, Delhi, India \\ ${ }^{2}$ M. Tech (Geotechnical Engineering), Department of Civil Engineering, Delhi Technological University, Delhi, India \\ ${ }^{3}$ Assistant Professor, Department of Civil Engineering, Sanskar College of Engineering \& Technology, Ghaziabad, \\ India
}

\begin{abstract}
The structure resulting from compacting the soil at different water contents and energy levels can have a substantial effect on its shear strength. While the shear strength can be estimated based on the saturated shear strength parameters and the unsaturated angle of shearing resistance, limited studies have explored the variation of shear strength properties with different compaction states. In the present study, shear behavior of virgin Yamuna sand and Yamuna sand blended with two clays of different mineralogy i.e. bentonite and kaolinite was investigated by Direct Shear test and Unconsolidated Undrained Tri-axial test. Index properties and compaction characteristics of soil are also studied in this project. It was aimed to observe the shear behavior of sand-bentonite and sand-kaolinite mixtures. Various tests conducted on virgin soil were performed for the determination of following parameters: field moisture content, Atterberg Limits, Grain Size Analysis, Standard Proctor Compaction test, Direct Shear and Triaxial Unconsolidated Undrained test. Compaction tests were conducted on mixtures of 5\%,10\%,15\%,20\% by weight bentonite and kaolinite. Direct Shear test and UU Triaxial tests were performed on mixes with 5\%,10\%,15\%,20\% by weight of bentonite and kaolinite. It was found that there is increase in MDD and OMC of the soil mixes for both kaolinite and bentonite. Maximum MDD was achieved with kaolinite clay and maximum OMC with bentonite clay. Direct shear test resulted in the increase in cohesion and decrease in friction angle for both bentonite and kaolinite. Similar results are obtained in UU Triaxial tests. However, shear parameters obtained in Direct Shear test is slightly more than obtained in Triaxial tests.
\end{abstract}

Keywords: Shear Behavior, Yamuna Sand, Bentonite, Kaolinite.

\section{INTRODUCTION}

\subsection{General}

Yamuna sand is chiefly found alongside the river Yamuna in Delhi .It has low load carrying capacity and also get eroded easily. Delhi lies in the seismic zone 4 which is high damage risk or seismic active zone. Moreover, Yamuna sand in Delhi as well as NCR region contains remarkable quantity of silt and thus it is in peril to liquefaction during earth tremor below ground water table. At several places ground water is at shallow depth and structures built over sand under such conditions are not safe. Therefore, understanding the shear behavior of Yamuna sand and its improvement in shear strength is necessary. One of the best method to improve the strength of sand is to blend it with soft soil. Soft soil is mainly clay that is expansive in nature, highly compressible, low permeability; have high specific surface and large water holding capacity as well as cohesion when come in contact with water. There are two type of clays used in the present study namely: 1) bentonite clay and 2) kaolinite clay.

Bentonite clay is essentially absorbent aluminum phyllosilicate clay that contains primarily of montmorillonite mineral. It is highly plastic clay formed by the weathering of volcanic ash generally in presence of water. There are three types of bentonite based on the dominant element present in them:

1. Sodium bentonite

2. Potassium bentonite

3. Calcium bentonite

Sodium bentonite has property to enlarge several times of its dry mass in presence of water. It is used in several geotechnical explorations such as drilling mud for gas and oil wells,in boreholes, as a low permeability liner in various landfills etc.

Potassium bentonite has potassium as its main element. It is formed from the alteration of volcanic ash and contains illite clay mineral.

Calcium bentonite is fundamentally used as adsorbent in ionic solution and also in oils. It is important element in the fuller's earth which is used as an rinsing agent. Calcium bentonite can be converted into sodium bentonite by ion exchange process.

Bentonite is also used in several geotechnical works such as drilling mud, as a binder, purification, ground water barrier and also bentonite slurry walls used in modern construction. Sand- bentonite mixtures have been used as a liner in the landfills due to its low permeability. In the present study Yamuna sand has been mixed with varying proportions of 
bentonite and its effect on shear behaviour is studied. Bentonite used in the project was procured from a dealer in delhi.

Kaolinite is a clay mineral that has low swelling and shrinkage property. It also exhibits low cation exchange capacity. It has generally white color, soft and earthlike. It occurs in large quantity in soils that are formed by the chemical weathering of rocks in warm climates such as tropical rainforest. Rocks having kaolinite as main clay mineral are called as kaolin or china clay. In the present study an attempt has been made to study shear behavior of sand mixed with varying proportions of kaolinite clay. Kaolinite powder used in the present study was obtained from a dealer in Delhi.

\subsection{Objectives of Present Study}

- To determine the basic properties of Yamuna sand.

- To study the effect of different proportions of bentonite and kaolinite on the compaction characteristics of Yamuna sand.

- To study the effect of varying proportions of bentonite and kaolinite on shear strength parameters of Yamuna sand by direct shear test.

- To study the effect of different proportions of bentonite and kaolinite on shear strength parameters of Yamuna sand by UU tri-axial test.

- To compare the results obtained on mixing bentonite in varying proportions in Yamuna sand with results obtained on mixing kaolinite in different proportions in Yamuna sand.

\section{MATERIALS USED AND METHODOLOGY}

\subsection{Materials Used in Present Study}

\subsubsection{Sand}

In this project Yamuna sand is taken from the alongside of river Yamuna. It is firstly washed and the wetted soil is passed through $4.75 \mathrm{~mm}$ sieve and retained on 75 micron sieve, then soil is oven dried, is taken. This sand was subjected to various laboratory tests as per IS codes to determine particle size distribution, specific gravity, OMC $\&$ MDD etc.

Table 2.1: Geotechnical properties of Yamuna sand

\begin{tabular}{|l|l|}
\hline Properties & Values \\
\hline Sand content $(4.75-0.075 \mathrm{~mm}), \%$ & 92.4 \\
\hline Fine soil fraction $(<75 \mu), \%$ & 7.6 \\
\hline Coefficient of uniformity, $\mathrm{C}_{\mathrm{u}}$ & 1.37 \\
\hline Coefficient of curvature, $\mathrm{C}_{\mathrm{c}}$ & 2.87 \\
\hline Effective size of particle, $\mathrm{D}_{10}(\mathrm{~mm})$ & 0.0845 \\
\hline Soil classification & $\mathrm{SP}-\mathrm{SM}$ \\
\hline Specific Gravity & 2.65 \\
\hline Maximum dry density $(\mathrm{MDD}) \mathrm{kN} / \mathrm{m}^{3}$ & 16.94 \\
\hline Optimum moisture content $(\mathrm{OMC}), \%$ & 11.2 \\
\hline
\end{tabular}

\subsubsection{Bentonite Clay}

It is basically bentonite powder collected from a dealer in Delhi. It was subjected to various laboratory tests as per IS codes to determine particle size distribution, specific gravity, consistency limits etc.

Table 2.2: Geotechnical properties of Bentonite Clay

\begin{tabular}{|l|l|}
\hline Properties & Values \\
\hline Sand content $(4.75-0.075 \mathrm{~mm}), \%$ & 1.9 \\
\hline Fine soil fraction $(<75 \mu), \%$ & 98.1 \\
\hline Clay content $(<2 \mu), \%$ & 89.4 \\
\hline Liquid limit, $\%$ & 550 \\
\hline Plastic limit, $\%$ & 87.46 \\
\hline Soil classification & $\mathrm{CH}$ \\
\hline Specific gravity & 2.2 \\
\hline
\end{tabular}

\subsubsection{Kaolinite Clay}

It was purchased in powdery form from a dealer in Delhi. It was subjected to various laboratory tests as per IS codes to determine particle size distribution, specific gravity, consistency limits etc.

Table 2.3: Geotechnical properties of Kaolinite Clay

\begin{tabular}{|l|l|}
\hline Properties & Values \\
\hline Sand content $(4.75-0.075 \mathrm{~mm}), \%$ & 3.8 \\
\hline Fine soil fraction $(<75 \mu), \%$ & 96.2 \\
\hline Clay content $(<2 \mu), \%$ & 65.6 \\
\hline Liquid limit, $\%$ & 71.6 \\
\hline Plastic limit, $\%$ & 41.67 \\
\hline Soil classification & $\mathrm{OH}$ \\
\hline Specific gravity & 2.62 \\
\hline
\end{tabular}

\subsection{Sample Mixes Used in the Study}

Yamuna sand was mixed with the bentonite and kaolinite separately in different proportions and their effect on compaction behaviour and shear behaviour of the Yamuna sand was investigated. Sample mixes are as follows:

Table 2.4: Sample Mixes

\begin{tabular}{|l|l|}
\hline Sample name & Proportioning of materials \\
\hline SM0 & Virgin Yamuna sand \\
\hline SMB5 & 95\% Yamuna sand $+5 \%$ Bentonite \\
\hline SMB10 & $90 \%$ Yamuna sand $+10 \%$ Bentonite \\
\hline SMB15 & $85 \%$ Yamuna sand $+15 \%$ Bentonite \\
\hline SMB20 & $80 \%$ Yamuna sand $+20 \%$ Bentonite \\
\hline SMK5 & $95 \%$ Yamuna sand $+5 \%$ Kaolinite \\
\hline SMK10 & $90 \%$ Yamuna sand $+10 \%$ Kaolinite \\
\hline SMK15 & $85 \%$ Yamuna sand $+15 \%$ Kaolinite \\
\hline SMK20 & $80 \%$ Yamuna sand $+20 \%$ Kaolinite \\
\hline
\end{tabular}

\subsection{Laboratory Experiments Conducted}

The particle morphology of Yamuna sand, Bentonite clay and Kaoloinite clay was analyzed using scanning electron 
microscope in Nano Science Laboratory of DTU Delhi. Particle size analysis of Yamuna sand, Bentonite clay and Kaoloinite clay was carried out as per IS: 2720 (Part IV)1985. The specific gravity of Yamuna sand, Bentonite clay and Kaoloinite clay is determined as per IS: 2720 (Part III/Sec I)-1980. The liquid limit and plastic limit of Bentonite clay and Kaoloinite clay were determined as per the procedure lay down in IS: 2720 (Part V)-1985. MDD and OMC of Yamuna sand, Bentonite clay, Kaoloinite clay and sample mixes is determined as per IS: 2720 (Part VII) 1980. Direct shear test was conducted on sample mixes as per IS: 2720 (Part XIII)-1986 and UU Tri-axial test was conducted on various soil mixes as per procedure lay down in IS: 2720 (Part XI)-1993.

\subsubsection{Direct Shear Test}

This test was carried out on soil to determine the shear parameters of soil. A standard size $(60 \mathrm{~mm} \times 60 \mathrm{~mm})$ Direct Shear box was used for the investigation. The tests were conducted on three different normal stress i.e. 50, $100 \& 150$ $\mathrm{kPa}$ and the angle of internal friction \& cohesion values were obtained by plotting a straight line through the plot of shear stress versus the normal stress. Direct Shear tests were performed strictly according to IS: 2720 (Part XIII)-1986 on Yamuna sand and Yamuna sand mixed with different proportions of bentonite and kaolinite. All the tests were performed at MDD and OMC of the soil sample

\subsubsection{Unconsolidated Undrained (UU) Tri-axial}

\section{Test}

A series of unconsolidated and undrained triaxial compression tests was performed on virgin Yamuna sand and Yamuna sand blended with varying proportions of bentonite and kaolinite separately(10\%, $15 \%$ and 20\%). Tests were performed as per IS: 2720 (Part XI)-1993. All test specimens were $38 \mathrm{~mm}$ in diameter and $76 \mathrm{~mm}$ high. All tests were performed at MDD and OMC. The soil sample and amount of water is weighed and then mixed in the evaporating dish with the help of spatula. The mix is then poured in mould. The soil is compacted with a small tamper into three layers in a mould. After each compaction soil surface is scratched and next layer is filled and compacted. Sample was extracted from mould with the help of sample extractor machine. Sample was then placed in triaxial cell having porous stone with filter paper at bottom and glass stopper at top. Rubber membrane is then placed on the sample with the help of sampler. The cell in then filled with water and then required cell pressure is applied. Displacement is set to zero. Tests were performed at 1, 2, 3 $\mathrm{kg} / \mathrm{cm}^{2}$. Displacement $(\mathrm{mm})$ and load $(\mathrm{kg})$ readings were taken at regular intervals at $0.25 \mathrm{~mm}, 0.50 \mathrm{~mm}, 0.75,1.0 \mathrm{~mm}$, $1.25 \mathrm{~mm}$ and so on up to failure or $15.2 \mathrm{~mm}$ whichever is earlier. Then cell pressure was released and water from triaxial cell was drained. The sample was taken out carefully to observe the failure. In the present study 38 tests were performed of which 27 were successful. All the tests were performed at HEICO Engineering Services Pvt. Ltd., A13, Phase-2, Naraina Industrial Area, New Delhi.

\section{RESULTS AND DISCUSSIONS}

\subsection{Scanning Electron Microscope (SEM) Test}

\subsubsection{SEM Test on Yamuna sand}

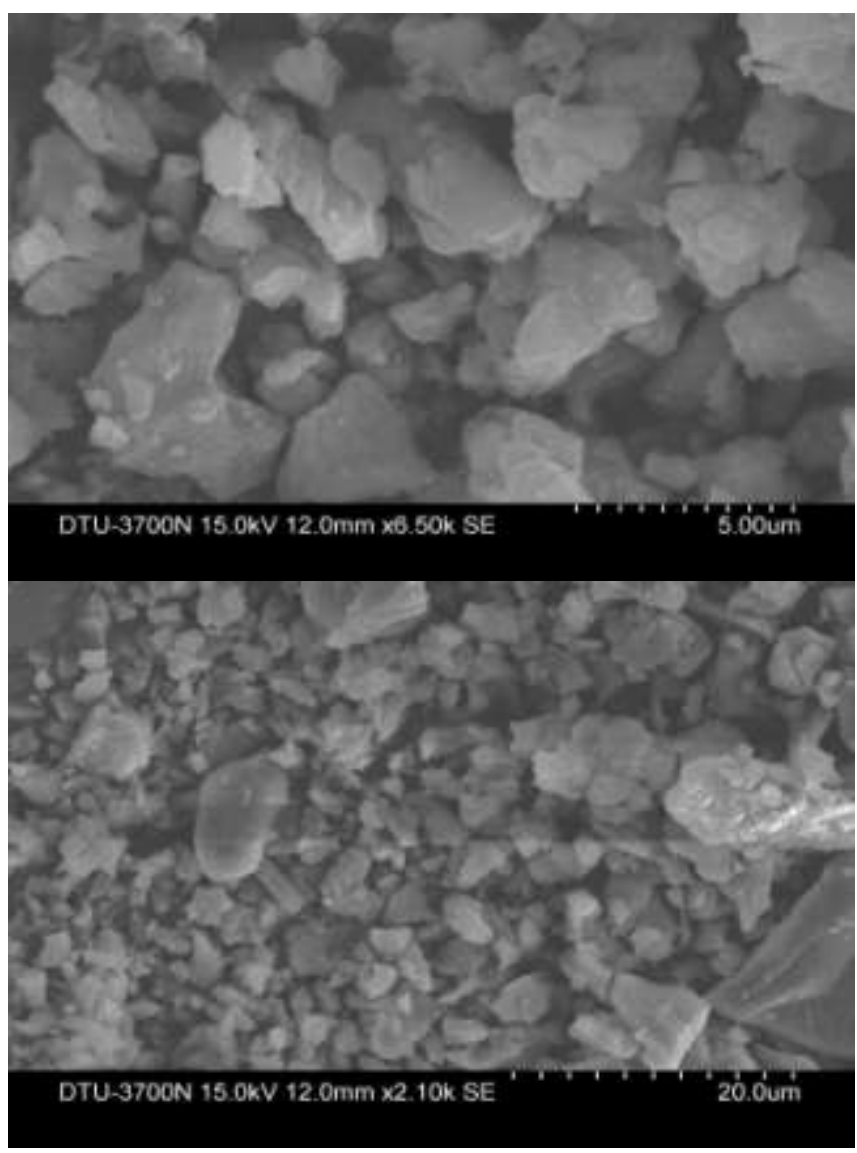

Fig. 3.1: Particle morphology of Yamuna sand

It has been observed from SEM images (Fig. 3.1) that Yamuna sand particles are angular, experienced non uniform weathering and has larger silica dissolution.

\subsubsection{SEM Test on Bentonite Clay}

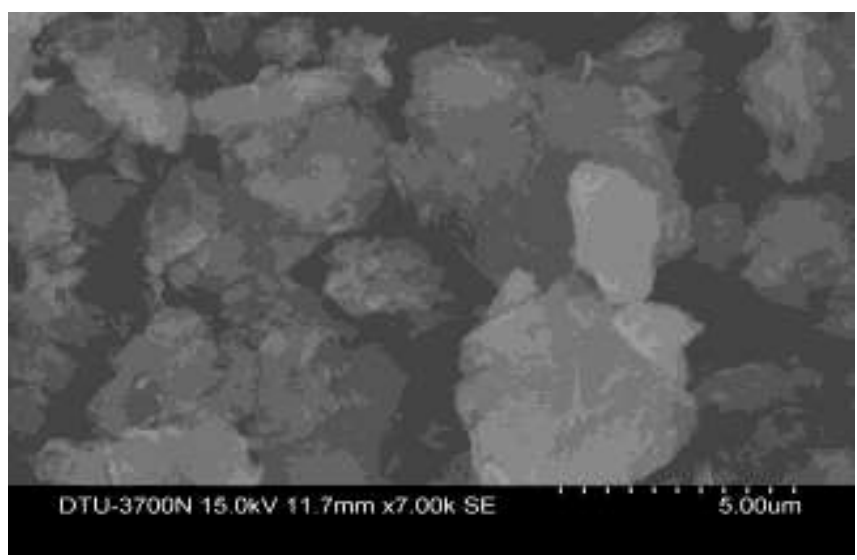




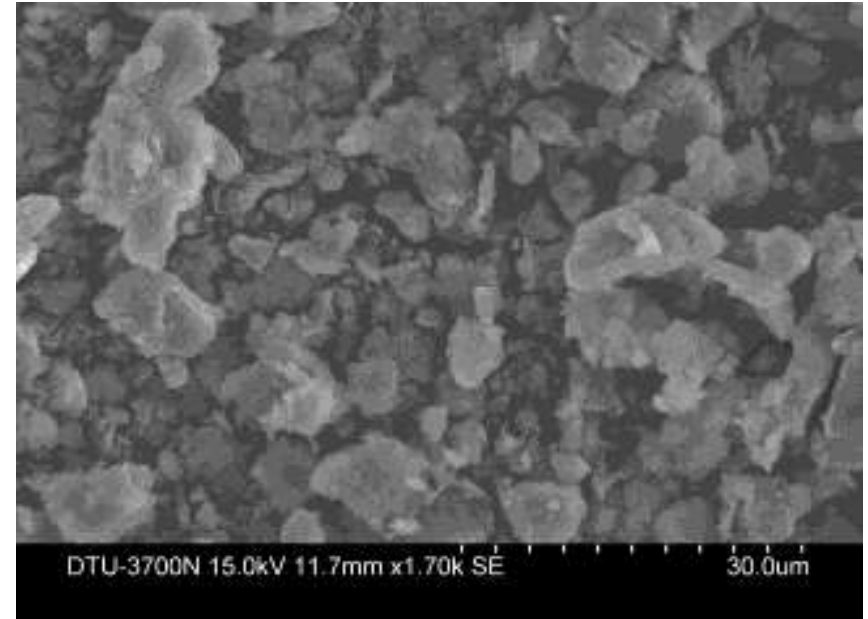

Fig. 3.2: Particle morphology of Bentonite clay

It can be seen in SEM images (Fig. 3.2) that particles present in bentonite sample are of irregular size and shape and having large voids. Moreover, it has agglomerated due to the presence of water in the atmospheric condition. This establishes the hygroscopic nature of bentonite.

\subsubsection{SEM Test on Kaolinite Clay}

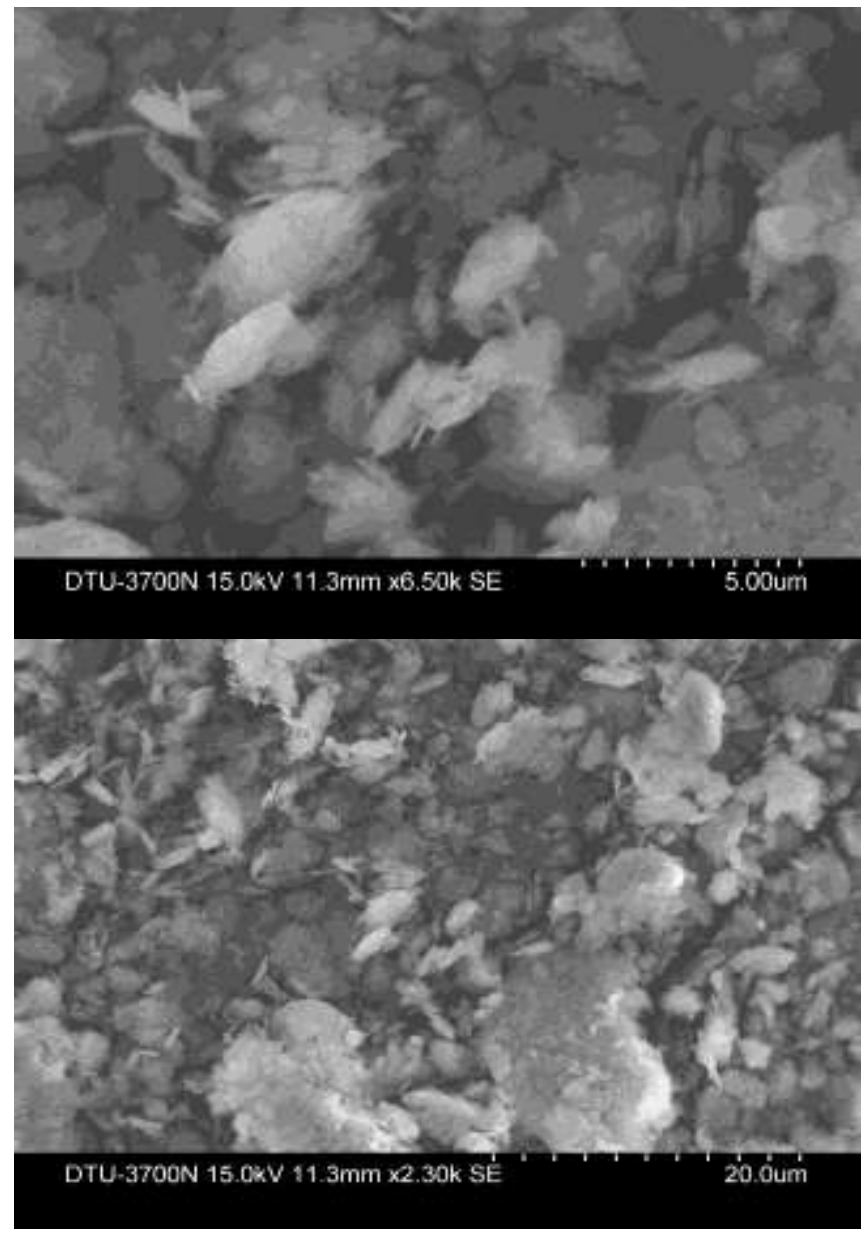

Fig. 3.3: Particle morphology of Kaolinite clay

It can be observed that particles present in bentonite sample are of irregular size and shape and having large voids.

\subsection{X-ray Diffraction (XRD) Test}

Various sample mixes was subjected to XRD test in Nano Science Laboratory of DTU Delhi and the results obtained are as follows:

\subsubsection{XRD Test on Yamuna sand}

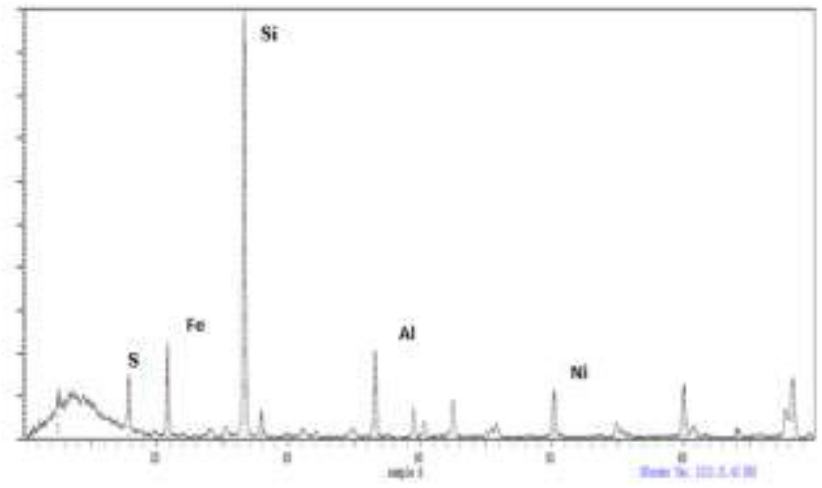

Fig. 3.4: XRD spectrum of Yamuna sand

It has been observed from XRD spectrum (Fig. 3.4) that Yamuna sand contains Sulphur, Nickel, Quartzite, Aluminum, and Silicon.

\subsubsection{XRD Test on Bentonite clay}

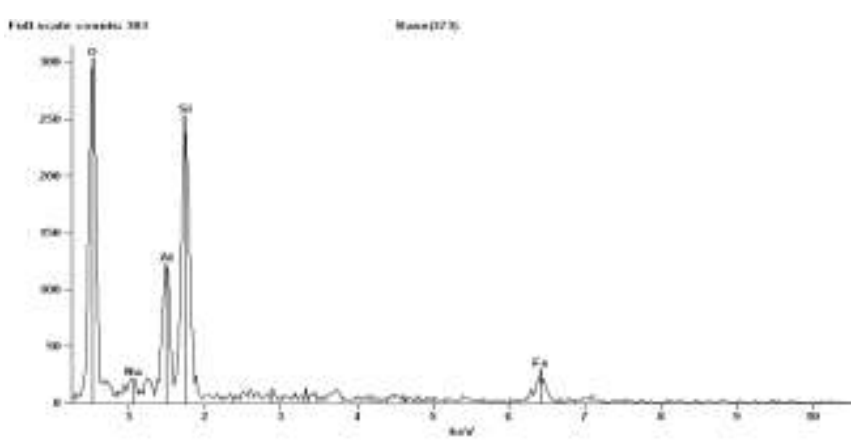

Fig. 3.5: XRD spectrum of bentonite clay

It has been observed from XRD spectrum (Fig. 3.5) that bentonite clay contains Sodium, Aluminum, Iron, Oxygen and Silicon. The spectrum achieved from the XRD shows that there are traces of sodium ions in bentonite samples which goes to show that the bentonite used in work is a type of sodium bentonite.

\subsubsection{XRD Test on Kaolinite clay}

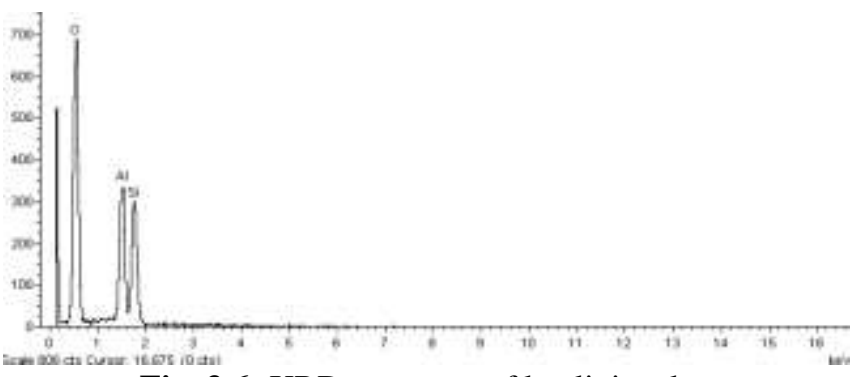

Fig. 3.6: XRD spectrum of kaolinite clay 
It has been observed from XRD spectrum (Fig. 3.6) that kaolinite clay contains Oxygen, Calcium, Aluminum, Iron, and Silicon.

\subsection{Light Compaction Test}

Compaction behavior of different sample mixes is shown in following figures:

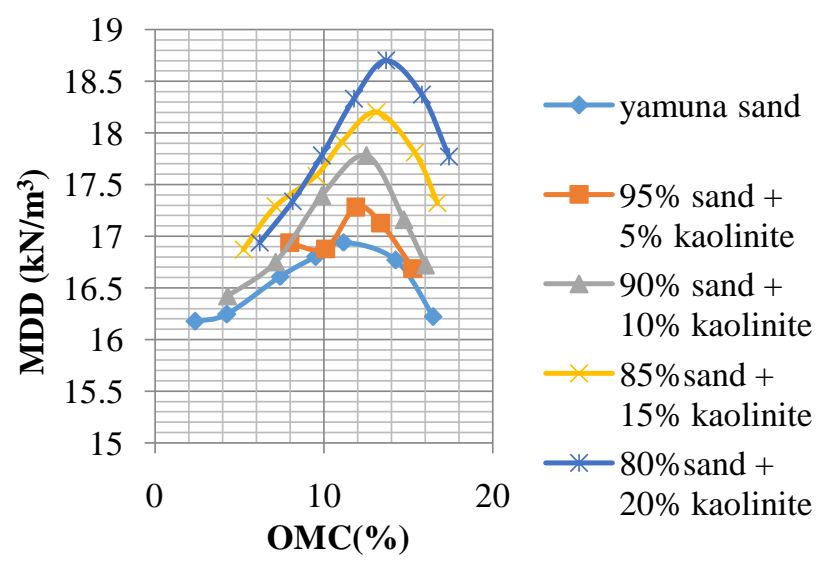

Fig. 3.7: Compaction behavior of Yamuna sand mixed with varying proportion of kaolinite clay

Table 3.1: Variation of OMC and MDD for various Yamuna sand-kaolinite mixes

\begin{tabular}{|l|l|l|}
\hline Sample & OMC $(\%)$ & MDD $\left(\mathrm{kN} / \mathrm{m}^{3}\right)$ \\
\hline Yamuna sand & 11.20 & 16.94 \\
\hline SMK5 & 11.87 & 17.28 \\
\hline SMK10 & 12.51 & 17.78 \\
\hline SMK15 & 13.11 & 18.20 \\
\hline SMK20 & 13.67 & 18.70 \\
\hline
\end{tabular}

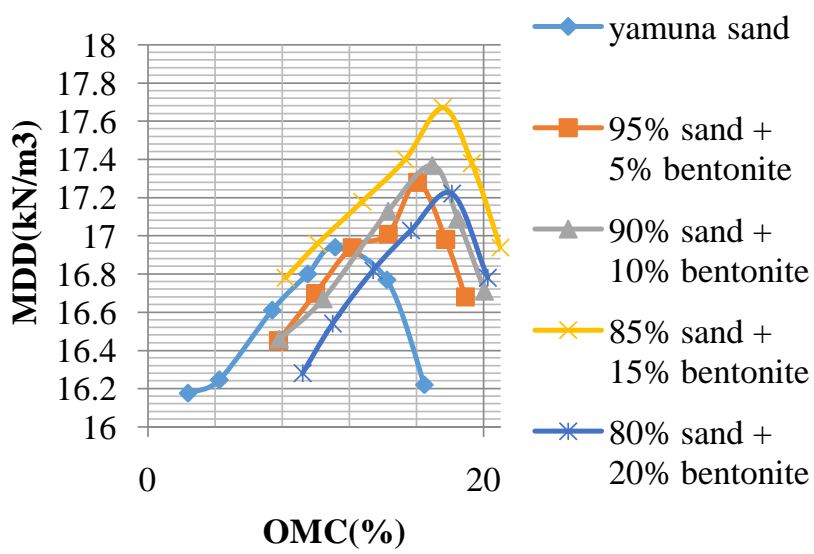

Fig. 3.8: Compaction behavior of Yamuna sand mixed with varying proportion of bentonite clay

Table 3.2: Variation of OMC and MDD for various Yamuna sand-bentonite mixes

\begin{tabular}{|l|l|l|}
\hline Sample & OMC $(\%)$ & MDD $\left(\mathrm{kN} / \mathrm{m}^{3}\right)$ \\
\hline Yamuna sand & 11.20 & 16.94 \\
\hline SMB5 & 16.05 & 17.24 \\
\hline
\end{tabular}

\begin{tabular}{|l|l|l|}
\hline SMB10 & 16.95 & 17.38 \\
\hline SMB15 & 17.56 & 17.67 \\
\hline SMB20 & 18.10 & 17.22 \\
\hline
\end{tabular}

\subsection{Direct Shear Test}

Shear behavior of different sample mixes is shown in the following figures:

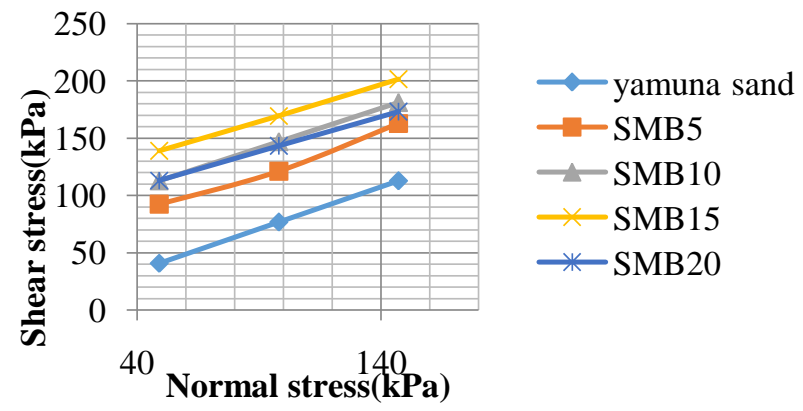

Fig. 3.9: Shear behavior of various Yamuna sand-bentonite mixes

Table 3.3: Variation of shear strength parameter $(c-\phi)$ for various Yamuna sand-bentonite mixes

\begin{tabular}{|l|l|l|}
\hline Sample & Cohesion, c $(\mathrm{kPa})$ & $\phi($ Degree $)$ \\
\hline Yamuna sand & 4.91 & 36.31 \\
\hline SMB5 & 54.63 & 35.62 \\
\hline SMB10 & 78.43 & 34.91 \\
\hline SMB15 & 107.53 & 32.49 \\
\hline SMB20 & 83.53 & 31.38 \\
\hline
\end{tabular}

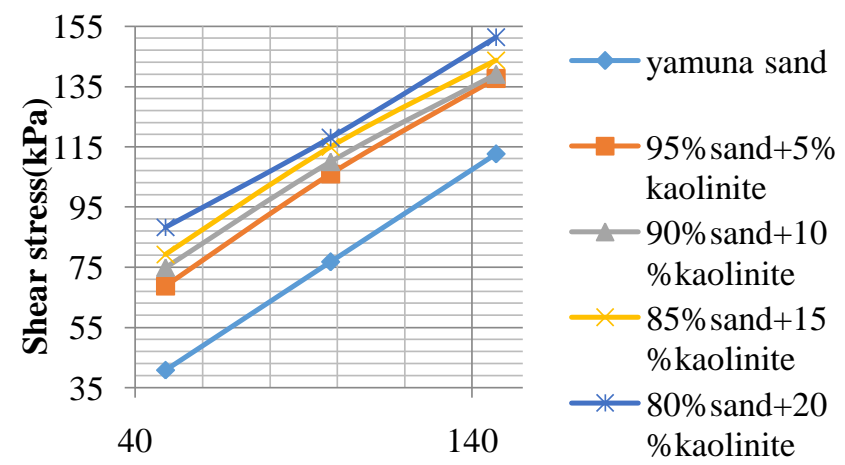

Normal strss(kPa)

Fig. 3.10: Shear behavior of various Yamuna sand-kaolinite mixes

Table 3.4: Variation of shear strength parameter $(c-\phi)$ for various Yamuna sand-kaolinite mixes

\begin{tabular}{|l|l|l|}
\hline Sample & Cohesion, c $(\mathrm{kPa})$ & $\phi($ Degree $)$ \\
\hline Yamuna sand & 4.91 & 36.31 \\
\hline SMK5 & 35.28 & 35.06 \\
\hline SMK10 & 43.85 & 34.71 \\
\hline SMK15 & 47.07 & 32.91 \\
\hline SMK20 & 56.22 & 32.62 \\
\hline
\end{tabular}




\subsection{Unconsolidated Undrained Tri-axial Test}

Deviator stress vs. axial strain behavior is shown in the following figures:

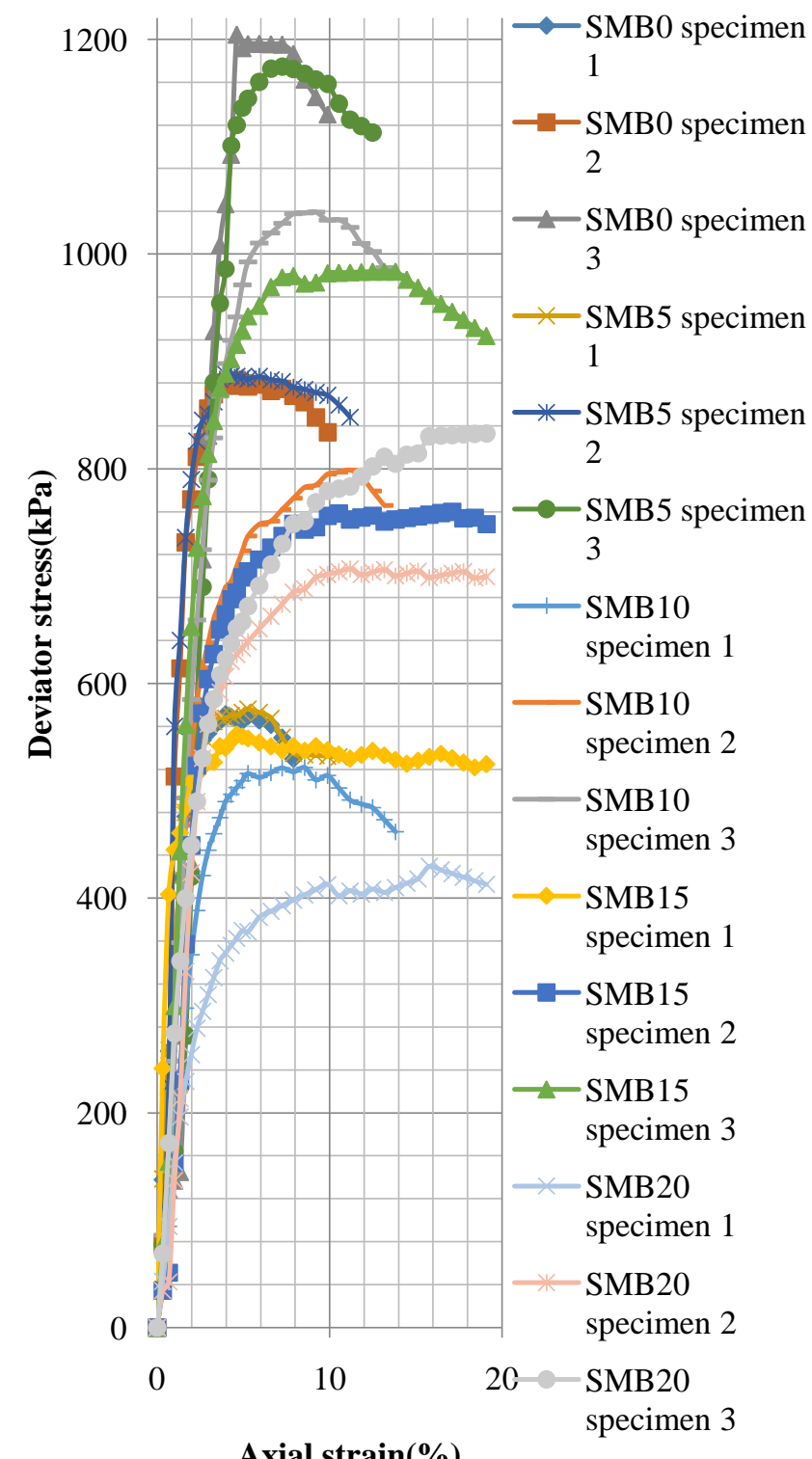

Axial strain(\%)

Fig. 3.11: Deviator stress vs. axial strain curve variation for various Yamuna sand-Bentonite mixes

Table 3.5: Variation of shear strength parameter $(c-\phi)$ for various Yamuna sand-bentonite mixes

\begin{tabular}{|l|l|l|}
\hline Sample & Cohesion, c $(\mathrm{kPa})$ & $\phi($ Degree $)$ \\
\hline Yamuna sand & 3.92 & 35.90 \\
\hline SMB5 & 50.01 & 34.70 \\
\hline SMB10 & 74.53 & 34.10 \\
\hline SMB15 & 93.15 & 31.60 \\
\hline SMB20 & 69.62 & 30.80 \\
\hline
\end{tabular}

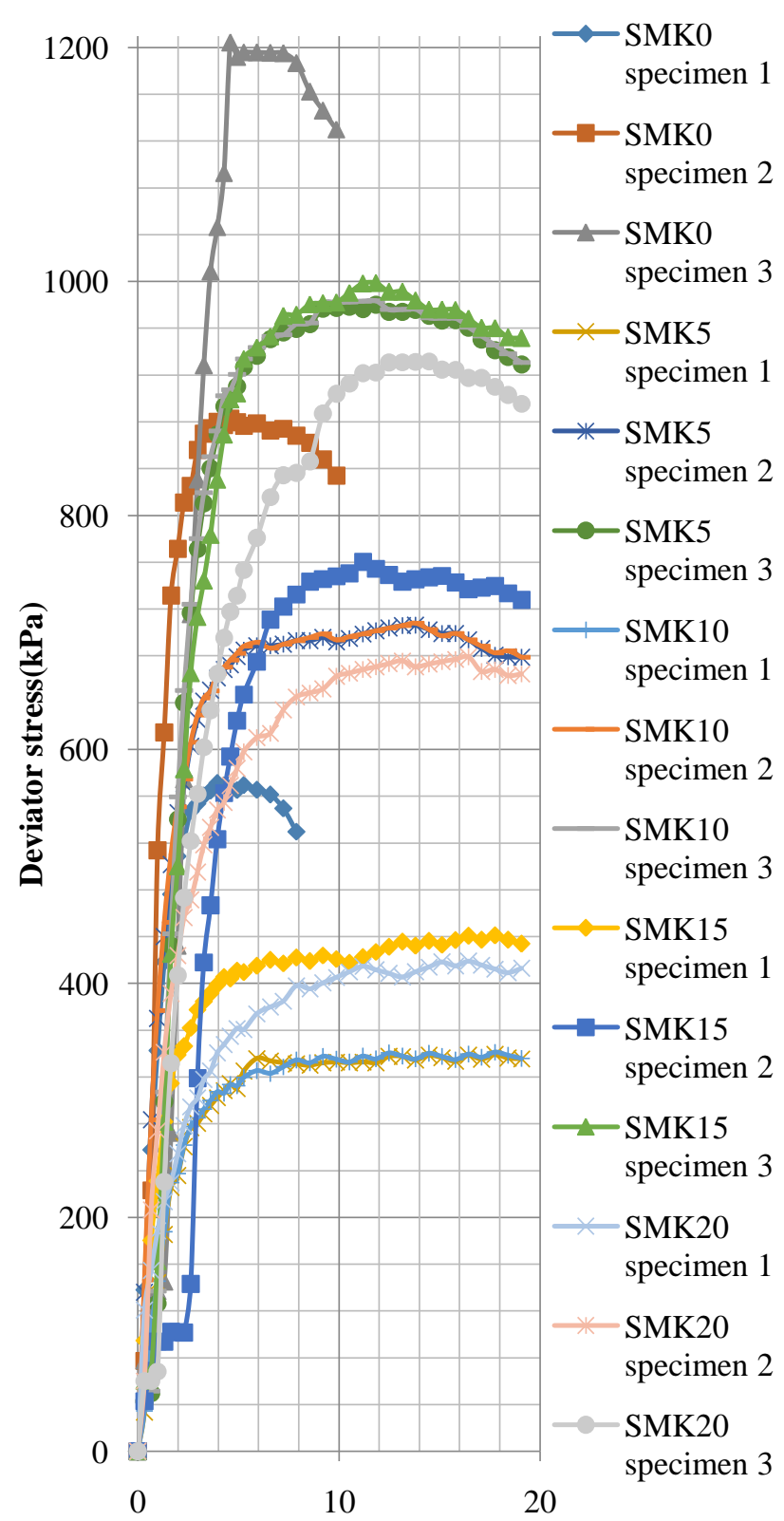

Axial strain(\%)

Fig. 3.12: Deviator stress vs. axial strain curve variation for various Yamuna sand-Kaolinite mixes

Table 3.6: Variation of shear strength parameter $(c-\phi)$ for various Yamuna sand-kaolinite mixes

\begin{tabular}{|l|l|l|}
\hline Sample & Cohesion, c $(\mathrm{kPa})$ & $\phi($ Degree $)$ \\
\hline Yamuna sand & 3.92 & 35.90 \\
\hline SMK5 & 23.53 & 35.40 \\
\hline SMK10 & 36.28 & 33.90 \\
\hline SMK15 & 40.20 & 32.90 \\
\hline SMK20 & 50.99 & 32.10 \\
\hline
\end{tabular}




\section{CONCLUSION}

This research was carried out to study the effect of bentonite and kaolinite on compaction behavior and shear behavior of Yamuna sand yielded following conclusions:

\section{Light Compaction Test}

1. With the increase in bentonite content there is increase in OMC of the soil mix having maximum value at $20 \%$. This may be attributed to the high specific surface and large water holding capacity of bentonite.

2. As the bentonite content increases there is increase in MDD upto $15 \%$ and then MDD decreases at $20 \%$. The reason for this might be that bentonite particles fill the voids of the sand thereby increasing maximum dry density upto $15 \%$ and afterwards decrease in MDD is due to the fact that clay particles start taking up the space which would have been taken by the sand.

3. With the increase in kaolinite content there is increase in OMC of the soil mix which is due to the high specific surface of kaolinite.

4. As the kaolinite content increases there is increase in MDD of the soil mix. The maximum value of MDD is at $20 \%$ mix. This due to the fact that kaolinite particles fill the voids of the sand thereby increasing MDD.

\section{Direct Shear Test}

1. There is increase in cohesion with the increase in bentonite and kaolinite content.

2. Angle of internal friction decreases as the bentonite and kaolinite content increased with max decrement at $20 \%$ for both type of clays.

3. Increase in cohesion is more pronounced in case of bentonite as compared to kaolinite.

4. Angle of internal friction decreased more in case of bentonite as compared to kaolinite.

\section{UU Tri-axial Test}

1. There is increase in cohesion for both bentonite and kaolinite content increment.

2. Angle of internal friction decreased as the bentonite and kaolinite content increased.

3. For bentonite maximum value of cohesion is 93.15 $\mathrm{kPa}$ whereas in case of kaolinite, it is $50.99 \mathrm{kPa}$.

4. Moreover, it has been observed that $C-\phi$ values obtained from direct shear test are slightly more than the values observed from UU tri-axial test.

\section{REFERENCES}

[1]. Dafalla M. A., (2013), "Effects of Clay and Moisture Content on Direct Shear Tests for Clay-Sand Mixtures", Advances in Materials Science and Engineering.

[2]. Georgiannou, Burland, and D. W. Hight (1990), “The Undrained Behaviour of Clayey Sands in Triaxial
Compression and Extension", Geotechnique 40, No.30, 431449.

[3]. Georgiannou V. N. (1988), "Behavior of Clayey Sands under Monotonic and Cyclic Loading" Ph.D. thesis, Department of Civil Engineering, Imperial College of Science, Technology and Medicine, London, England.

[4]. Ojha S. and Trivedi A., (2013), "Shear Strength Parameters for Silty Sand Using Relative Compaction", EJGE, Vol.18.

[5]. Panwar P. and Ameta N. K., (2013), "Stabilization of Dune Sand with Bentonite and Lime", EJGE, Vol.18.

[6]. Pakbaz M. S. and Moqaddam A. S., (2013), "Effect of Sand Gradation on The Behavior of Sand-Clay Mixtures" International Journal of Geomate, Vol. 3, No. 1 (S1. No. 5), pp. 325-331.

[7]. Purvana Y. M., Nikraj H. and Jitsangiam P., (2012), "Experimental Study of Suction-Monitored CBR Test on Sand-Kaolin Mixture", International Journal of Geomate, Vol.3, No.2 (SI.No.6), pp. 419-422.

[8]. Rao, C. H. and Ramana, G. V., (2010), "Characterization of Cyclic Strength of Yamuna Sand", International Journal of Earth Sciences and Engineering ISSN 0974-5904, Vol. 03, No. 02, pp. 234-242.

[9]. Sourav De, and Basudhar, P.K., (2008) , Steady State Behaviour of Yamuna Sand" Geotech Geol Eng.

[10]. Simpson D. C. and Evans T. M., (2015), “Behavioral Thresholds in Mixtures of Sand and Kaolinite Clay", $J$. Geotech. Geoenviron. Eng., ASCE, 2016, 142(2): 04015073.

[11]. Tiwari, A., Suman, S., and Sharma, S., (2016), "Study of Compacted Sand-Bentonite Mixture as Material of Low Hydraulic Conductivity Liner of Landfill for Solid Waste Disposal", Imperial Journal of Interdisciplinary Research, Vol-2, Issue-4.

[12]. IS 2720 (Part IV): 1985, "Method of test of soilsGrain size analysis", Bureau of Indian Standards.

[13]. IS 2720 (Part III/Sec II): 1980, "Method of test of soils- Determination of specific gravity", Bureau of Indian Standards.

[14]. IS 2720 (Part V): 1985, "Method of test of soilsDetermination of liquid limit and plastic Limit", Bureau of Indian Standards.

[15]. IS 2720 (Part VII): 1980, "Determination of Water Content -Dry Density Relation Using Light Compaction”, Bureau of Indian Standards.

[16]. IS 2720 (Part XIII): 1986, "Method of test of soilsDirect shear test", Bureau of Indian Standards.

[17]. IS 2720 (Part 11): 1993, "Determination of the Shear Strength Parameters of a Specimen Tested in Unconsolidated Undrained Triaxial Compression Without the Measurement of Pore Water Pressure", Bureau of Indian Standards. 